\title{
Design, Simulation through the computer and Implementation in a protoboard of a simple lie detector circuit
}

\author{
Andrés Caicedo Raffo ${ }^{1}$ y Mauricio Toro ${ }^{2}$ \\ ${ }^{1}$ Pontificia Universidad Javeriana Cali \\ ${ }^{2}$ Universidad EAFIT
}

\begin{abstract}
This paper contains the process of design, simulation and elaboration of a lie detector circuit based on the variation of the skin electric resistance. It includes surveys, graphs, numerical data and different conclusions about the implementation, design and simulation of the circuit.

Resumen: Este documento contiene información acerca del proceso de diseño, simulación y elaboración de un circuito detector de mentiras basado en la variación de la resistencia eléctrica de la piel. En este paper se incluyen encuestas, datos numéricos y diferentes conclusiones acerca de la implementación, diseño y simulación de este circuito.
\end{abstract}

Key Words: Lie detector, lying, simple circuit, electronic technology.

\section{INTRODUCTION}

Students of Electronics Engineering built their first circuit in second semester for Electronic technology class. By the same time, Informatics Engineering students start their courses about simulation modeling, identification and simulation of dynamical systems and circuits. In this paper is going to be studied one of the simplest circuits that can be built by the second semester students. These circuit is a simple lie detector, which is not as sophisticated as the ones that have been built lately, but has the basics that second semester students should know about their future, because it is something that if going to be apply in the fore coming semesters.

As it was mentioned above, the lie detector is one of the simplest circuits that can be built. The design and implementation of the lie detector is important because it can improve the knowledge about the support that a circuit can give to humans in their daily life and the design of circuits in a protoboard. The main objective of this paper is to apply the theory studied in the electronic technology class and the simulation class, the other objective is to learn about the implementation of circuits on protoboards and the recognition of the functioning of the electronic elements. In the following paragraph is explained how some of this elements function.

Many condensators are used to store electric current, like the circuit implemented for this paper, in this circuit the condensator stops the travel of electric current to the electrodes and that way, the subjects tested with this circuit do not receive a discharge of electric current. The other element used in the circuit, which is very important, is the transistor which is used to amplify the current because the one in the circuit is very small. The transistor allows the travel of electric current between the base and the collector which are parts of the transistor, in order to take the signals used in the analog meter and be able to read the resistance of the subject's skin in a accurate way. The meter should be analog and it should have a very good accuracy that is not always displayed in a digital one or in a normal meter. In the lie detector, this element is the one that shows whether the person in lying or not, because the analog meter has a needle which oscillates proportionally with the travel of electrical current through it. When the needle oscillates too much, it means that the subject is lying.

Process calculi have been applied to the modeling of interactive music systems [36, 35 , $33,29,34,28,42,31,32,27,30,26,41$, $48,25,47,1,43,37,6,23,20,22,24,2$, $40,21,38,39,19]$ and ecological systems $[45,9,46,10]$. In addition, research on 
algorithms $[7,5,15,11,13,16,14,44,3$, 8], software engineering [18, 4], precision agriculture [51] and intelligent transport systems $[12,17,49,50]$ also contributes to this field.

\section{SYSTEM MODEL}

Everything in the world has a resistance to electricity that is measured in Ohms $(\Omega)$ [55]. The skin of the humans has a very interesting characteristic. When humans lie, their skin resistance goes down and this principle it is used to build a lie detector. The circuit has electrodes that are attached to the back of the subject's hand. The electrodes can be alligator clicks (although they can be painful), electrode pads (like the ones they use in the hospital), or just wires and tape [55]. Besides, the device is a pot that is a variable resistor, which means that its resistance can be changed. Its use is very important because not everybody's skin has the same resistance, so these pots have a switch that permits to change the resistance, so the user should twist the port until the current through the analog meter is zero. The analog meter works with the current that is passing through it when the current increase. The oscillation of the needle is larger, which means that the frequency in the circuit changed.

\section{PARTS USED IN THE CIRCUIT}

$\begin{array}{lll}\text { Part } & \text { Qty. Description } \\ \text { R1 } & 1 & \text { 33K 1/4W Resistor } \\ \text { R2 } & 1 & \text { 5K Pot } \\ \text { R3 } & 1 & \text { 1.5K 1/4W Resistor } \\ \text { C1 } & 1 & \text { 1uF 16V Electrolytic Capacitor } \\ \text { Q1 } & 1 & \text { 2N3565 NPN Transistor } \\ \text { M1 } & 1 & \text { 0-1 mA Analog Meter } \\ \text { MISC } & 1 & \text { Case, Wire, Electrodes }\end{array}$

That's why when the subject is lying; the resistance of the skin is going to be less, which permits the easy passing of the electricity[54]. When this happens, and analog meter, that is connected to the electrodes changes and then it can be shown if a person is lying or not.

One of the main abilities that are applied for a better understanding of the circuits is the handling of schematics, which is a graph of the circuit. The schematics can be graph through a computer program that helps students to elaborate them before building the circuit on a protoboard [54]. The protoboard is a board that it is used to design the internal parts of the devices, it is also used to create and to optimize the distributions of the electronic pieces.

When the circuit construction was begun, the first pieces used were the electrodes and the condensator because then it was easier to follow the schematic.

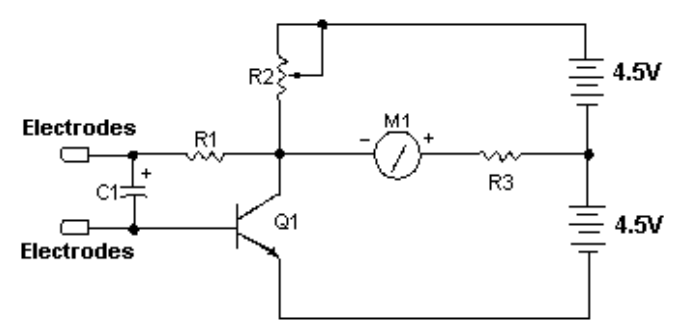

[53]

Through a computer program called P-Spice (see picture bellow) or Eagle we can design a schematic and simulate the lie detector circuit. Thanks to the computer it is possible to calibrate the circuit in order to have a very efficient and painless lie detector. The program manages the different electric resistors on the market, and it also displays and illustration of its functioning [54]. The computer screen works like a protoboard, every time a device is chosen it is displayed and simulated.

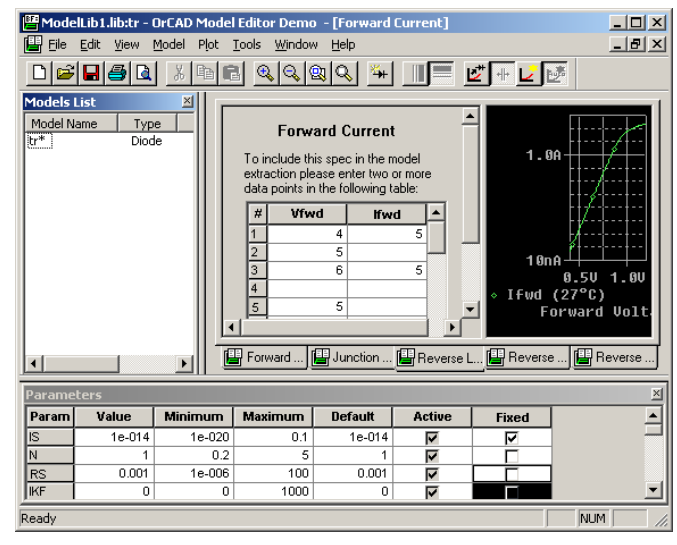




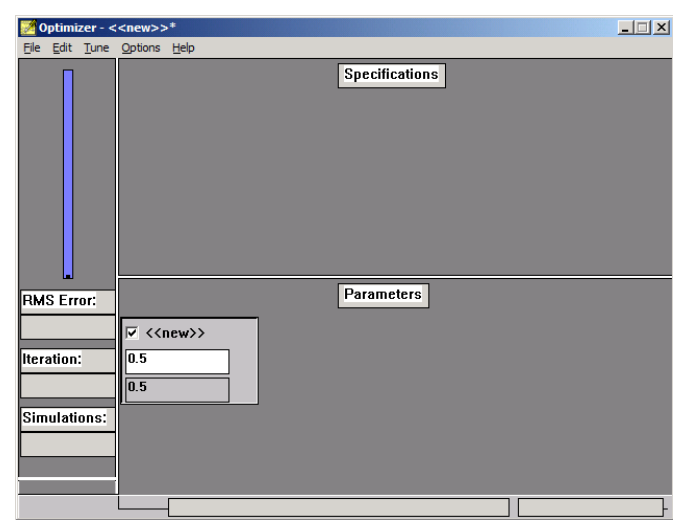

LIE DETECTOR SIMULATED IN SPICE

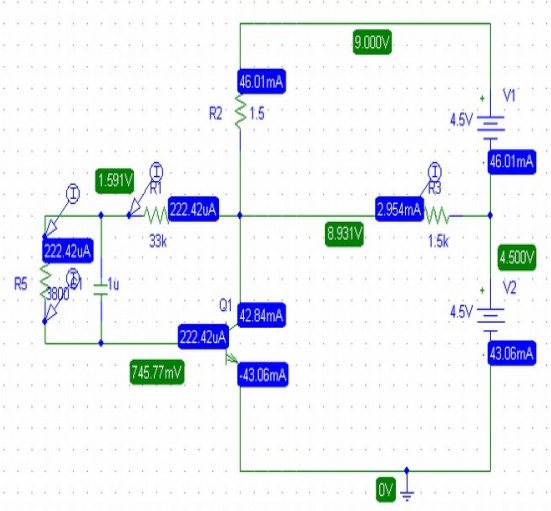

Pspice program showed in the schematic above the current (green) and the voltage (blue) that the circuit produces, which helped to analyze the circuit.

Following the analysis on Pspice, it was deduced that in order to make the current changes enough, the resistance should be more than $3000 \Omega$.

Then in the oscilloscope it was graph the waves that were generated before they reach the amperimeter and the R3 resistance and it was showed that each time the resistance changed, the graph amplitude change, it means that the voltage was changes proportionally to the resistance. The waves were sine type, but they had some imperfections.

The graph below shows a simulation in pspice of how the oscilloscope shows the behavior of the circuit.

\section{RESULTS SHOWED BY PSPICE AFTER THE SIMULATION}

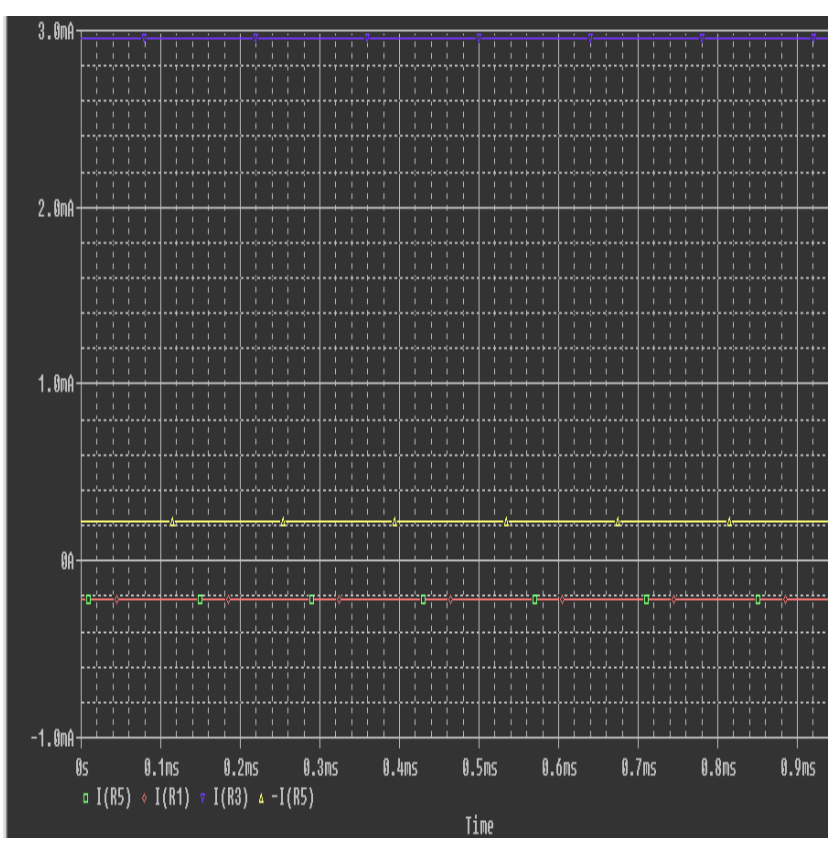

\section{RESULTS SHOWED BY PSPICE AFTER THE SIMULATION OF THE LOGIC GATES}

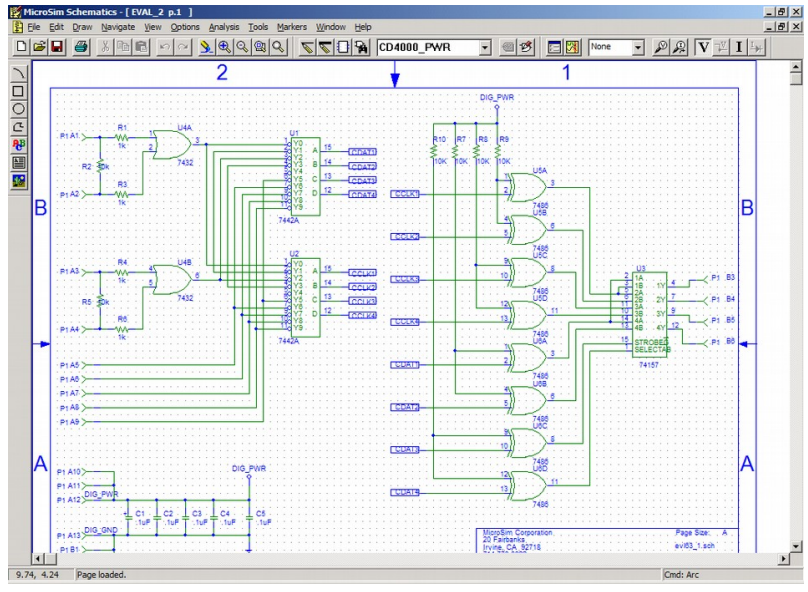

Although the lie detector device is often very accurate, some problems may occur when external factors affect the skin of the subject to be tested [52]. External factors such as water, humidity and barometric pressure may change the electric resistance of the skin and the reading might be wrong. Besides those external factors, the ability of the persons who design and build the device, because their work can affect the functioning and design of the circuit.

\section{NUMERICAL RESULTS}

- $\quad \mathrm{R}_{\text {Total }}=\left(\mathrm{R}_{1}+\mathrm{R}_{2}\right)-$ Rprel 
- $\quad$ Req $=\mathrm{R} 1+\mathrm{R} 2+\mathrm{R} 3 \ldots+\mathrm{RN}$ serial connection

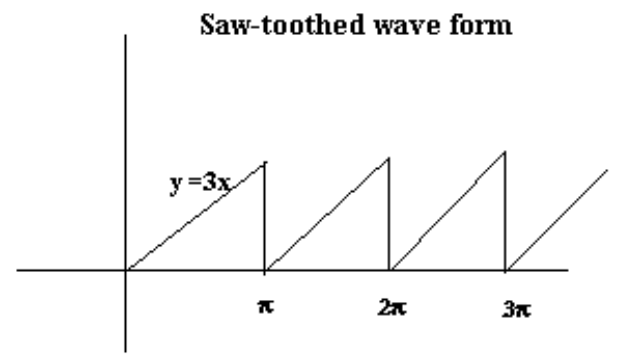

The saw-toothed wave clearly describes the behavior of the circuit under normal and constant conditions. When the electrical resistance doesn't change the frequency of the current describes a saw-toothed wave.

- $\quad 1 /$ Req $=1 / \mathrm{R} 1+1 / \mathrm{R} 2+1 / \mathrm{R} 3 \ldots 1 / \mathrm{RN}$ parallel connection

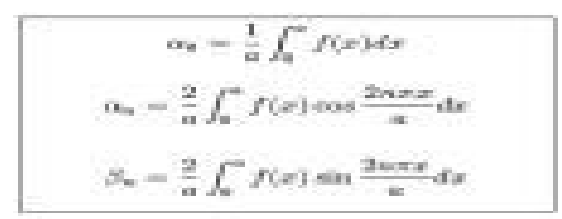

Partial derivates and integrals can be easy applied into circuits in order to calculate the resistance of parallel connected circuits and through Laplace transformation it is possible to calculate the condensator's equation.

- Condensator $=(\mathrm{R} 1 * \mathrm{R} 2+\mathrm{R} 2 * \mathrm{R} 3+$ $\mathrm{R} 1 * \mathrm{R} 3) * \mathrm{C} 1 /(\mathrm{R} 1+\mathrm{R} 2+\mathrm{R} 3)$

- $\quad$ RTotal $=35 \Omega+25 \Omega-12,6 \Omega=47,4$ $\Omega$

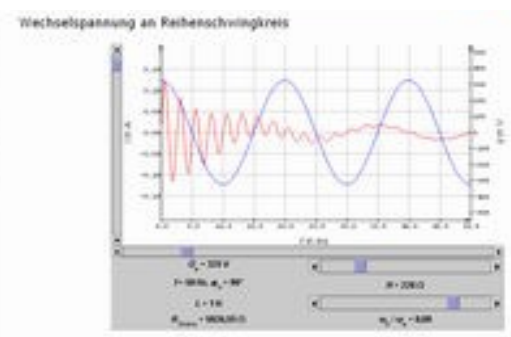




$\begin{array}{cc}\begin{array}{c}\text { Resistor R2 } \\ \text { (M ohm) }\end{array} & \begin{array}{c}\text { Current R4 } \\ \text { (Ampere) }\end{array} \\ 3800 & 1 \\ 3900 & 0,999 \\ 4000 & 0,998 \\ 4100 & 0,997 \\ 4200 & 0,996\end{array}$

\section{ERRORS DURING THE SIMULATION}

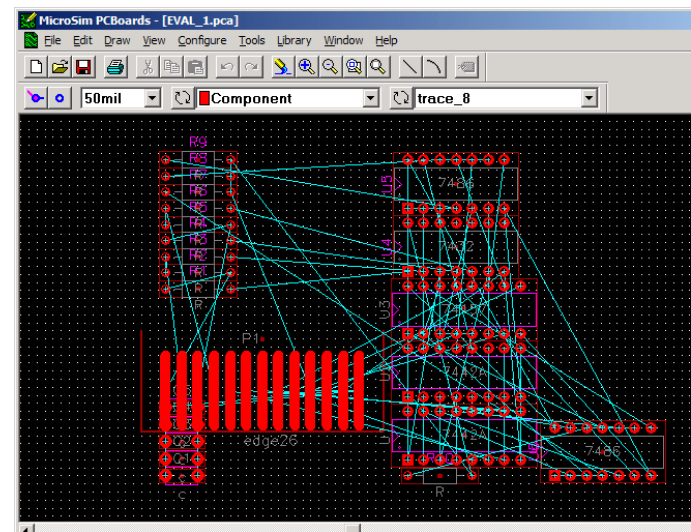

$\frac{1}{3000.00,0250.00} \quad$ Ready $\quad \perp$

This simulation has errors because the ways are cross between each other, besides that they are not organized in an optimized way.

When the electrical resistance changes the frequency of the current describes sine graph as the one show above.

Calculation of the output frequency

$\mathrm{F}=(\mathrm{R} 1+\mathrm{R} 2) / 3 \mathrm{R} 1=(35 \Omega+25 \Omega) / 75 \Omega$ $=0,8 \Omega$

$\begin{array}{cc}\begin{array}{c}\text { Resistor R2 } \\ \text { (M Ohm) }\end{array} & \begin{array}{c}\text { Current R3 } \\ \text { (Ampere) }\end{array} \\ 1 & 1,5 \\ 2 & 1,84 \\ 3 & 1,96 \\ 4 & 2,03 \\ 5 & 2,07\end{array}$

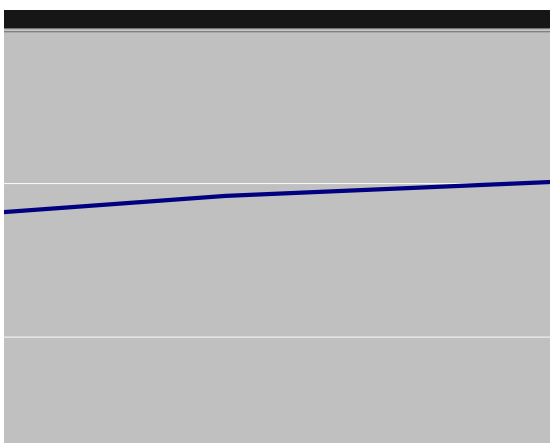

in the graph above it is shown the variation of the current when the resistor $\mathrm{R} 2$ changes.

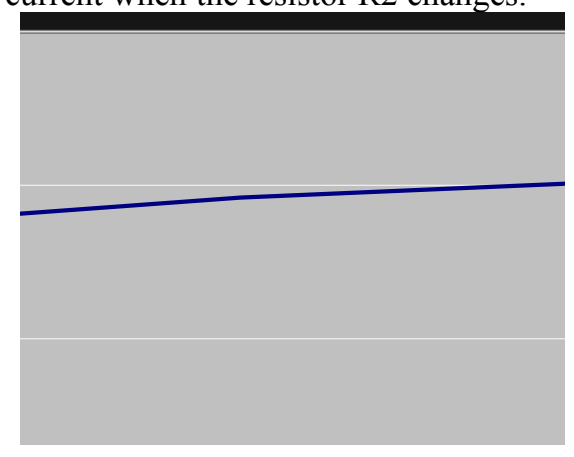

CONCLUSIONS

Finally it is possible to infer that a long term application of this project is to interrogate persons involved on different crimes and genocides. The lie detector is a very good circuit to be built in second semester because it gibes the basics that are going to be important afterwards. The simulation of the circuit before the elaboration was very important in order to prevent future failures and inefficient distribution of the components.

About the simulation and data analysis the following conclusion were obtained:

- P spice is a very good simulator that helps with the analysis of circuits.

- It is important to apply the theory studied in technology class

The handling of instruments in the university is very easy, in order to build a electronic circuit and simulate it thought the computer it should be followed some steps: First, an schematic map should be made, it should contain all the parameters necessary to the construction of the circuit, second the simulation of the circuit must be done and finally it is necessary to make some tests. We realized that the great resistance of the human skin is measured in mega-ohms and that not all the skins have the same resistance and conductibility to electricity, the components used in the circuit have a function that is designated according to each one characteristics.

\section{REFERENCES}

[1] Allombert, A., Desainte-CAtherine, M., AND Toro, M. Modeling temporal constrains for a system of interactive score. In Constraint Programming in Music, G. Assayag and C. Truchet, Eds. Wiley, 2011, ch. 1, pp. 1-23.

[2] Aranda, J., Assayag, G., Olarte, C., Pérez, J. A., Rueda, C., Toro, M., And Valencia, F. D. An overview 
of FORCES: an INRIA project on declarative formalisms for emergent systems. In Logic Programming, 25th International Conference, ICLP 2009, Pasadena, CA, USA July 14-17, 2009. Proceedings (2009), P. M. Hill and D. S. Warren, Eds., vol. 5649 of Lecture Notes in Computer Science, Springer, pp. 509-513.

[3] Arcila, V., Piedrahita, I., AND Toro, M. Robotic bees: Algorithms for collision detection and prevention. arXiv e-prints (May 2019), arXiv:1905.11822.

[4] Mazo, R., Toro, M., And Cobaleda, L. Definicion de la arquitectura de referencia de un dominio: de la elucidacion al modelado. In Guia para la adopcion industrial de lineas de productos de software, R. Mazo, Ed Editorial Eafit, 2018, pp. 193-210.

[5] Moreno, J. D. A., Passos, S., And Toro, M. On-line assembling mitochondrial DNA from de novo transcriptome. CoRR abs/1706.02828 (2017).

[6] Olarte, C., Rueda, C., Sarria, G., Toro, M., AND VALENCIA, F. Concurrent Constraints Models of Music Interaction. In Constraint Programming in Music, G. Assayag and C. Truchet, Eds. Wiley, Hoboken, NJ, USA., 2011, ch. 6, pp. 133-153.

[7] PAtiÑo-Forero, C., Agudelo-Toro, M., AND Toro, M. Planning system for deliveries in Medellín. ArXiv eprints (Nov. 2016)

[8] Perez Bernal, G., Toro Villegas, L., And Toro, M. Saber pro success prediction model using decision tree based learning. arXiv e-prints (2020).

[9] Philippou, A., AND Toro, M. Process Ordering in a Process Calculus for Spatially-Explicit Ecological Models. In Proceedings of MOKMASD'13 (2013), LNCS 8368, Springer, pp. 345-361.

[10] PhilipPou, A., Toro, M., AND ANTONAKI, M. Simulation and Verification for a Process Calculus for Spatially-Explicit Ecological Models. Scientific Annals of Computer Science 23, 1 (2013), 119-167.

[11] Quintero, E., SANCHEZ, M., RoldAN, N., AND TORO, $\mathrm{M}$. Genetic algorithm for optimal distribution in cities. ArXiv e-prints (Nov. 2018)

[12] RamíRez, T., CAStañeda, L., AND Toro, M. Sistema inteligente para transporte público tipo SETP. In XIII Congreso Colombiano de Transporte y Tránsito, Movilizando el futuro de Colombia (2019), Universidad Tecnológica de Bolívar, p. 57.

[13] Rendon, C., Hernández, J. L., Ruiz-SAlguedo, O., Álvarez, C. A., AND Toro, M. Wing Profile Evolution driven by Computational Fluid Dynamics. In Tecnologías Avanzadas de Mecatrónica, Diseño y Manufactura: Memorias Cuarto Congreso AMDM (2018), Editorial Universidad Autónoma de Manizales, pp. 345-347.

[14] Rendon, C., Hernández, J. L., Ruiz-Salguedo, O., Álvarez, C. A., AND Toro, M. Wing Profile Evolution driven by Computational Fluid Dynamics. Revista UIS Ingenierías 19, 2 (2019), 139-146.

[15] Restrepo, J. M. C., Palacio, A. F. Z., AND Toro, M. Assembling sequences of DNA using an on-line algorithm based on debruijn graphs. CoRR abs/1705.05105 (2017).

[16] Rodriguez, J., Escudero, D., AND Toro, M. Data Structure for efficient indexing of files and directories. Research Gate (2018).
[17] Sagbini, K., RamíreZ-Guerrero, T., CAStañeda, L., AND TORO, M. Aplicaciones móviles para la evaluación de conductores y usuarios en Sistemas Estratégicos de Transporte Público. Desafios en Ingeniería: Investigación Aplicada (2019)

[18] Suescún, E., Toro, M., Mazo, R., Velasquez, D. VALlejo, P., CARdona, J. F., Rincón, R., WERnECK, V. M., AND do Prado Leite, J. C. C. SimulES-W: A Collaborative Game to Improve Software Engineering Teaching. Computación y Sistemas 22, 3 (2018), 953-983.

[19] TORO, M. Exploring the possibilities and limitations of concurrent programming for multimedia interaction and graphical representations to solve musical csp's. Tech. Rep. 2008-3, Ircam, Paris.(FRANCE), 2008.

[20] Toro, M. Probabilistic Extension to the Factor Oracle Model for Music Improvisation. Master's thesis, Pontificia Universidad Javeriana Cali, Colombia, 2009.

[21] TORO, M. Towards a correct and efficient implementation of simulation and verification tools for probabilistic ntcc. Tech. rep., Pontificia Universidad Javeriana, May 2009

[22] TORO, M. Structured interactive musical scores. In Technical Communications of the 26th International Conference on Logic Programming, ICLP 2010, July 16-19, 2010, Edinburgh, Scotland, UK (2010), M. V.

Hermenegildo and T. Schaub, Eds., vol. 7 of LIPICs, Schloss Dagstuhl - Leibniz-Zentrum fuer Informatik, pp. 300-302.

[23] TORO, M. Structured Interactive Scores: From a simple structural description of a multimedia scenario to a realtime capable implementation with formal semantics. $\mathrm{PhD}$ thesis, Univeristé de Bordeaux 1, France, 2012.

[24] TORO, M. Structured interactive music scores. CoRR abs/1508.05559 (2015).

TORO, M. Probabilistic Extension to the Concurrent Constraint Factor Oracle Model for Music Improvisation. ArXiv e-prints (Feb. 2016).

[25] TORO, M. Probabilistic Extension to the Concurrent Constraint Factor Oracle Model for Music Improvisation . Inteligencia Artificial 57, 19 (2016), 37-73.

[26] Toro, M. Backtracking-free interactive music scores with temporal relations over rythms. OSF Preprints 10.31219/osf.io/bwzsk (Oct 2018).

[27] Toro, M. Combining temporal relations and signal processing into interactive scores. OSF Preprints osf.io/sqmer (Oct 2018).

[28] Toro, M. Current Trends and Future Research Directions for Interactive Music. ArXiv e-prints (Oct. 2018).

[29] TORO, M. CURRENT TRENDS AND FUTURE RESEARCH DIRECTIONS FOR INTERACTIVE MUSIC. Journal of Theoretical and Applied Information Technology 69, 16 (2018), 5569-5606.

[30] TORO, M. Modeling michael jarrell's csp in gelisp. OSF Preprints osf.io/2ebzj (Oct 2018). TORO, M. ntccmc: A bounded-time model checker for ntcc. OSF Preprints osf.io/c8kah (Oct 2018).

[31] TORO, M. Towards a correct and efficient implementation of simulation and verification tools for probabilistic ntcc. ArXiv e-prints (Oct. 2018).

[32] TORO, M. Towards a correct and efficient implementation of simulation and verification tools for 
probabilistic ntcc. OSF Preprints 10.31219/osf.io/3wp5z (Oct 2018).

[33] Toro, M. Gelisp 1.0: A graphical interface for openmusic. OSF Preprints osf.io/w4yfe (Jan 2019).

[34] TORO, M. How to implement lightweight threads. $O S F$ Preprints osf.io/84tvj (Jan 2019).

[35] Toro, M., Agón, C., Assayag, G., And Rueda, C. Ntccrt: A concurrent constraint framework for real-time interaction. In Proc. of ICMC '09 (Montreal, Canada, 2009)

[36] Toro, M., AND Desainte-CATHERINE, M. Concurrent constraint conditional branching interactive scores. In Proc. of SMC '10 (Barcelona, Spain, 2010).

[37] Toro, M., Desainte-CATHERINe, M., AND BALTAZAR, P. A model for interactive scores with temporal constraints and conditional branching. In Proc. of Journées d'Informatique Musical (JIM) '10 (May 2010).

[38] Toro, M., Desainte-Catherine, M., AND CASTET, J. An extension of interactive scores for multimedia scenarios with temporal relations for micro and macro controls. In Proc. of Sound and Music Computing (SMC) '12 (Copenhagen, Denmark, July 2012).

[39] TORO, M., DESAINTE-CATHERINE, M., AND CASTET, J. An extension of interactive scores for multimedia scenarios with temporal relations for micro and macro controls. European Journal of Scientific Research 137, 4 (2016), 396-409.

[40] Toro, M., Desainte-CATHERINe, M., JANIN, D., AND ORLAREY, Y. Real-time interactive streams and temporal objects language. OSF Preprints 10.31219/osf.io/a6stk (Oct 2018)

[41] Toro, M., Desainte-CATHERINe, M., AND Rueda, C. Formal semantics for interactive music scores: a framework to design, specify properties and execute interactive scenarios. Journal of Mathematics and Music 8, 1 (2014), 93-112.

[42] TORO, M., AND LANIADO, H. Big data: historia, definición, herramientas y aplicaciones en la industria. Revista Virtual Pro 204 (2019), 1-5.

[43] Toro, M., Philippou, A., Arboleda, S., Puerta, M., AND VÉLEZ S., C. M. Mean-field semantics for a process calculus for spatially-explicit ecological models. In Proceedings of the Eleventh International Workshop on Developments in Computational Models, Cali, Colombia, October 28, 2015 (2016), C. A. Muñoz and J. A. Pérez, Eds., vol. 204 of Electronic Proceedings in Theoretical Computer Science, Open Publishing Association, pp. 79-94.

[44] Toro, M., Philippou, A., Kassara, C., AND SFENTHOURAKIS, S. Synchronous parallel composition in a process calculus for ecological models. In Proceedings of the 11th International Colloquium on Theoretical Aspects of Computing - ICTAC 2014, Bucharest, Romania, September 17-19 (2014), G. Ciobanu and D. Méry, Eds., vol. 8687 of Lecture Notes in Computer Science, Springer, pp. 424-441.

[45] TORO, M., RUEDA, C., AGÓN, C., AND ASSAYAG, G. Ntccrt: A concurrent constraint framework for soft realtime music interaction. Journal of Theoretical \& Applied Information Technology 82, 1 (2015).

[46] TORO, M., RUEDA, C., AGÓN, C., AND ASSAYAG, G. Gelisp: A framework to represent musical constraint satisfaction problems and search strategies. Journal of Theoretical \& Applied Information Technology 86, 2 (2016).
[47] VALENCIA, J. F., RAMÍREZ-GUERRERO, T. CAstañeda, L. F., AND TORO, M. Automatic detection of number-plate and traffic infractions of motorcyclists by intelligent transportation systems. IOP Conference Series: Materials Science and Engineering 844 (jul 2020), 012035.

[48] VALENCIA, J. F., RAMíREZ-Guerrero, T., CASTAÑEDA, L. F., AND TORO, M. Detección de infracciones y matrículas en motocicletas, mediante visión artificial, aplicado a sistemas inteligentes de transporte. RISTI - Revista Iberica de Sistemas e Tecnologias de Informacao 37 (2020).

[49] Velásquez, D., SÁnchez, A., SARMiento, S., Toro, M., MaIZA, M., AND SiERrA, B. A method for detecting coffee leaf rust through wireless sensor networks, remote sensing, and deep learning: Case study of the caturra variety in colombia. Applied Sciences 10, 2 (2020).

[52] BOYLESTAD, Robert . Teoria de Circuitos Electricos. México: Editorial Prentince Hall, 1999.

[53] COUGHLIN, Robert. Amplificadores operacionales y Circuitos Integrados Lineales. México: Editorial Prentice Hall, 1999

[54] DORF, Richard. Circuitos Electricos. México: Editorial Alfaomega. 2003

[55] EDMINISTER, Joseph. Circuitos Eléctricos. España: Editorial McGraw-Hill, 1997. 